\title{
THE USE OF PHYSICAL FACTORS FOR SEED QUALITY IMPROVEMENT OF HORTICULTURAL PLANTS
}

\author{
Marcela KRAWIEC ${ }^{1}$, Agata DZIWULSKA-HUNEK ${ }^{2 *}$, Krzysztof KORNARZYŃSKI $^{2}$ \\ ${ }^{1}$ Unit of Plant Nutrition, Institute of Horticultural Production, University of Life Sciences \\ Głęboka 28, 20-612 Lublin, Poland \\ ${ }^{2}$ Department of Biophysics, University of Life Sciences in Lublin \\ Akademicka 13, 20-950 Lublin, Poland
}

Received: October 2018; Accepted: April 2019

\begin{abstract}
Due to the common trend towards limitation of excessive use of chemicals in agriculture, there is a growth of interest in methods of seed quality improvement that would be safe for the environment. These include methods based on the effect of various physical factors, such as laser light, magnetic field, seed treatment with magnetized water, electric field. The work provides detailed information on the impact of seed stimulation of these factors on germination, growth, development and yielding of horticultural plants. Summarizing the results of the study, it can be concluded that the application of physical factors in appropriate doses can be an effective way to enhance many plant parameters that increase their productivity. The beneficial effects of seed stimulation are mainly related to the first stages of plant life, i.e. - germination, emergence and growth of seedlings. In many cases, the enhancement of these features is also the result of the increase of plant yields. The increase of yield is even several dozen percent. The results of the study encourage the implementation of these physical methods of seed quality improvement into agricultural and horticultural practice.
\end{abstract}

Key words: Electric field, laser light, magnetic field, magnetized water, seed germination, yield

\section{INTRODUCTION}

The production of high quality sowing material is the main task of seed industry (Finch-Savage $\&$ Bassel 2016). To produce such sowing material, numerous conditions have to be fulfilled, e.g. - favorable weather conditions, correct cultivation and protection of parent plants. Proper cultivation technology at seed plantations, including rational plant nutrition, has a significant effect on the biology of blooming, fruit setting, chemical composition and physiological properties of fruits. Sowing material of high quality should be characterized by varietal and physical purity, health, suitable germination capacity and vigor (Ellis 1992). It should be easy to sow and supplied with everything that facilitates germination, emergence, rapid plant growth and easy plant care. To meet the requirements of customers, seed companies subject seeds, after harvest, to a variety of treatments improving their quality. Such treatments include priming, pelleting, strapping, conditioning etc. However, due to the common trend towards limitation of excessive use of chemicals in agriculture, there is a growth of interest in the methods of improvement of seed quality and health status that would be safe for the environment. Apart from biological methods, we should mention here certain methods based on the effect of various physical factors, such as laser light, electric field, magnetic field, seed treatment with magnetized water.

The aim of the paper is to present the results of a study concerned with the possibility of application of such methods for the improvement of seed quality of horticultural plants. 


\section{Laser light}

The word laser comes from the first letters of the English name of the device - Light Amplification by Stimulated Emission of Radiation. Laser is a device producing coherent monochromatic light with a parallel beam. Thanks to the small width of emission line and parallel beam, laser radiation can be sharply focused on a very small area, resulting in high surface density of energy (Hoffmann 1996).

Studies conducted so far indicate a favorable stimulating effect of pre-sowing treatment of seeds with laser light on the germination, plant growth and development, and on the quantity and quality of yields of crop plants (Koper 1994; Vasilevski \& Bosev 1997; Podleśny \& Podleśna 2004; Muszyński \& Gładyszewska 2008; Aladjadjiyan 2011).

The effects of laser radiation depend on many different parameters, i.e. - wavelength, time of exposure, power, dose, and method of irradiation (constant or pulse) (Hernandez et al. 2010). Also important are the features of the seeds themselves, e.g. - their orientation during irradiation, genetic traits (species, variety) and physiological properties (health status, seed quality) (Hernandez et al. 2010; Podleśny et al. 2012; Krawiec et al. 2015).

In a vast majority, experiments with laser stimulation of seeds are conducted with the use of a helium-neon laser (He-Ne), though there have been instances of using semiconductor, ruby, nitrogen, argon, diode lasers, and lasers with $\mathrm{CO}_{2}$ (Hernandez et al. 2010). The domination of experiments with the use of the He-Ne laser is related to its characteristic wavelength of $632.4 \mathrm{~nm}$. That wavelength corresponds to the red light which, next to the far red, is responsible for the activation of phytochrome, important in plant physiology. Changes in the content of phytochrome forms ( $\mathrm{Pr}$ and $\mathrm{Pfr}$ ) regulate important life processes of plants, e.g. - seed germination (Brutnell 2006).

It is most common to use low power lasers and relatively long irradiation times (Koper 1993), or lasers with greater power and short times of irradiation, measured in milli-, and sometimes also picoseconds ( $10^{-12}$ second) (Wilde et al. 1969; Podleśny 2000). A laser can be classified as operating in either continuous or pulsed mode, depending on whether the power output is essentially continuous over time or whether its output takes the form of pulses of light on one or another time scale (Aladjadjiyan 2011). Apart from determining the dose or radiation, the number of irradiations is also very important. It is commonly believed that seeds should be irradiated several times, with small radiation doses, to eliminate the possibility of mutations (Inyushin et al. 1981). Therefore, in most studies, 3-5 irradiation treatments are applied, the time of irradiation being several seconds.

From the agrophysical point of view, laser stimulation makes use of the ability of seeds to absorb and store light energy, to transform it into energy stored in chemical compounds, and to use it subsequently in seed germination and then in plant growth and development (Gładyszewska 2011). Although the mechanisms of laser stimulation have not been understood entirely, it is found that laser stimulation of plants results in an increase of their bioenergetic potential, leading to higher activation at phytochrome, phytohormone and fermentative systems, as a stimulation of their biochemical and physiological processes (Vasilevski 2003; Hernandez et al. 2010). According to Chen et al. (2005a, b), $\mathrm{He}-\mathrm{Ne}$ laser radiation causes the induction of phytochrome. Subsequently, the activities of related enzymes, which were modulated by phytochrome could be enhanced. It leads to an increase of the entropy and internal energy of seeds during germination. Finally, the biochemistry and physiology metabolism of the cell speeds up. The increase of biophoton emission is related to the acceleration of cell division and growth of seedlings.

The aim of most of the experiments conducted so far was to determine the effect of laser stimulation on the process of seed germination. Positive effects of laser irradiation on germination energy and capacity, on the dynamics of seed germination, and on the quality parameters of seedlings have been demonstrated.

In a three-year study, Klimont (2002) achieved an improvement of germination energy of cucumber seeds as a result of 2-, 4- and 6-time irradiation with helium-neon laser, relative to the control. Increase in the number of irradiations caused an increase of germination energy. Depending on the number of irradiations, the germination energy increased by 
$1.3-15.8 \%$. In another experiment by Klimont (2001), the effect of several-time irradiation of pea seeds was increase in the germination energy by 20 $23.6 \%$. In both experiments of Klimont (2001, 2002), laser stimulation did not significantly affect the germination capacity of cucumber and pea seeds. Drozd and Szajsner (2007) demonstrated a favorable effect of laser stimulation on germination energy and capacity of three cucumber cultivars. An improvement of germination energy was observed after the application of three- and fivetime irradiation, while a significant increase of germination capacity was noted after the application of all of the laser radiation doses (1-, 3- and 5-time irradiation with laser with power of $200 \mathrm{~mW} \cdot \mathrm{cm}^{-2}$ ). In a study by Krawiec et al. (2016), an increase of germination capacity of scorzonera seeds (10.5-13.2\%) was demonstrated relative to non-irradiated control. Germination capacity enhanced with increase of the number of irradiations from 1 to 5 . The highest germination capacity and the fewest abnormal seedlings were noted after 5-time irradiation of seeds.

A study conducted by Muszyński and Gładyszewska (2008) demonstrated that radish seed irradiation with $\mathrm{He}-\mathrm{Ne}$ laser caused an improvement of the FGP (final germination percentage) compared to control seeds, although that depended on seed germination temperature. The criterion of germination was the penetration of seed coat by the germ, the germ length being equal to that of the seed. Irradiation enhanced the FGP only during germination at temperature of $20{ }^{\circ} \mathrm{C}$ (optimal for radish seeds germination according to the ISTA). No positive effect of seed stimulation with laser on increase in the FGP was noted under the conditions of low temperature $\left(15^{\circ} \mathrm{C}\right)$. No significant differences were found out between the control seeds and seeds treated with laser light in terms of the mean germination time. The authors concluded that laser light did not affect the germination process determining parameters related with elapsed time $\left(T_{1}, T_{50}, T_{25-75}, T_{10-90}\right)$.

Irradiation of seeds of Acacia farnesiana $\mathrm{L}$. with He-Ne laser light caused an improvement and acceleration of seed germination (Soliman \& Harith 2010). Seeds of the species remain dormant due to the impermeability of seed coat to water. Seed treatment with laser light caused perforation of seed coat at one or at several places. An increase of exposure time (from 1 to $9 \mathrm{~min}$ ) and intensity (from 0.03 to $1.70 \mathrm{~W} \cdot \mathrm{cm}^{-2}$ ) of $\mathrm{He}-\mathrm{Ne}$ laser light irradiation caused an increase of germination percentage and germination speed determined by Maguire coefficient and reduced the time of germination. In addition, an increase in irradiance and exposure time of $\mathrm{He}-\mathrm{Ne}$ laser light irradiation increased the levels of endogenous promoting substances (GA and IAA) and decreased the levels of endogenous inhibiting substances (ABA and phenol) in seed coats.

An increase in the concentration of IAA in seeds treated with laser light was also noted by other authors (Podleśny et al. 2012; Podleśna et al. 2015). IAA concentration in germinating seeds of pea increased with the advance of the process of germination. Seedlings grown from laser treated seeds had a higher content of IAA than control seedlings (Podleśna et al. 2015). IAA belongs to the auxins. This phytohormone is also formed in the seeds. It activates cell division in plant tissue and affects the elongation of cells (Murphy 2006). There is no evidence that IAA participates in the germination process or in the radical emergence, but later events seedling growth - might be controlled by the hormone (Bewley \& Black 1985). It appears that an increased level of IAA in seedlings, resulting from pre-sowing irradiation of seeds, may determine stronger dynamics of growth of crop plants.

The results of the studies conducted by certain authors indicate a positive effect of pre-sowing irradiation on the growth of seedlings (Drozd \& Szajsner 2007; Podleśny et al. 2012). As a result of presowing irradiation of seeds, an elongation of the aboveground part of seedlings of broad bean was noted (Podleśny et al. 2012), and an elongation of the hypocotyl of cucumber seedlings (Drozd \& Szajsner 2007). Laser irradiation of seeds can cause an elongation of radicles of cucumber (Drozd \& Szajsner 2007), peppers (Szajsner \& Drozd 2007), and scorzonera (Krawiec et al. 2015, 2016).

Certain studies indicate that germination improvement and acceleration as a result of laser irradiation of seeds is preceded by increased activity of some enzymes, i.e. - amylase and protease (Perveen et al. 2010; Podleśny et al. 2012; Podleśna et al. 2015), that could support the hypothesis of Chen et 
al. (2005a, b) about the mechanism of laser exposure. Treatment of pea seeds with $\mathrm{He}-\mathrm{Ne}$ laser caused an increase in the activity of amylolytic enzymes during the process of germination. The least stimulating effect was noted at the early stages of germination, before the seeds were fully swollen. The activity of amylolytic enzymes in pea seeds intensified with the passage of time and attained its maximum 120 hours after sowing (Podleśna et al. 2015). Stimulation of the enzymatic activity of amylase and protease after the application of laser radiation was also observed in sunflower seeds (Perveen et al. 2010). However, the greatest enzymatic activity of amylase was noted considerably earlier, as soon as after 48 hours from sowing. That acceleration resulted probably from the fact that in that experiment, the seeds were soaked in water for 3 hours prior to irradiation.

Laser light can be used for the improvement of the health status of seeds. In an experiment on the effect of He-Ne laser light on the survival of fungi in seeds of rape, Dakowska et al. (2001) found, for certain cultivars and microorganisms, a directly proportional relation between the duration of irradiation and seed health. The number of fungal colonies was notably reduced, especially in the case of spring rapeseed. That phenomenon was observed at shorter times of irradiation, of 30 and 90 minutes. In a study by Wilczek et al. (2005), irradiation with intensity of $6 \mathrm{~mW} \cdot \mathrm{cm}^{-2}$, applied 3 and 5 times, destroyed fungi from the genus Penicillium and inhibited the occurrence of fungi from the genus Alternaria (isolated from the seeds of alfalfa sowing material).

Some studies demonstrated that pre-sowing stimulation of seeds with laser light can modify the emergence of seedlings (Hernandez et al. 2006; Krawiec \& Dziwulska-Hunek 2009; Podleśna et al. 2015). Irradiation of pea seeds caused an acceleration of emergence by 2 days (Podleśna et al. 2015). In the research of Hernandez et al. (2006), the laser irradiation of maize seeds significantly increased the seedling emergence rate (Maguire coefficient) and field emergence. The highest positive responses were found when the treatment time was 30 and 60 seconds and the intensities were 3.2 and $20 \mathrm{~mW} \cdot \mathrm{cm}^{-2}$, respectively. An intensity of $20 \mathrm{~mW} \cdot \mathrm{cm}^{-2}$ for $60 \mathrm{sec}-$ onds produced significant increases in seedling emergence rate $(43 \%)$, in dry weight $(63 \%)$ and emergence (48\%), compared to the control.

In a study by Krawiec and Dziwulska-Hunek (2009), an increase in the emergence rate (by 22$24 \%$ ) was an effect of irradiation of only old seeds of pea (with initial germination capacity of 62.0 and $76.3 \%$ ). No such response was noted in the case of seeds with high quality parameters (germination capacity of $88.8-95.0 \%$ ). In addition, the study demonstrated that pre-sowing laser stimulation caused an acceleration of emergence obtained from seeds of poorer quality (old) by 1.1-2.4 days.

Research shows that laser irradiation has a positive effect on traits shaping the yielding of plants. Podleśna et al. (2015) demonstrated that laser irradiation of seeds can cause an increase of pea leaf area and SPAD index, which is related with the content of chlorophyll in leaves and is an indicator of photosynthetic activity. In a study by Hernandez et al. (2010), laser stimulation of seeds caused an increase in chlorophyll content in maize leaves.

Laser stimulation of seeds causes an increase in the yield of generative and vegetative organs of plants and an improvement of its quality. In an experiment conducted by Gładyszewska et al. (1998), irradiation of seeds of greenhouse cucumber with divergent beam of He-Ne laser (method of adjustable doses of energy) caused an increase in fruit yield by 16 to $31.5 \%$, depending on the cultivar. In a study by Koper (1994), the increase of yield of fruits of greenhouse and field cucumber was 5-60\% and $10-25 \%$, respectively. As a result of laser stimulation of seeds, the yield of greenhouse and field tomatoes increased by $10-30 \%$ and $10-20 \%$, respectively, relative to the control. Plants of those species attained their harvest ripeness earlier. The early yield of greenhouse tomato (up to $1 / 3$ of the cropping time) increased by about $27-60 \%$ compared to the control. Whereas, the early yield of greenhouse cucumber increased by $31 \%$. In addition, the seedlings grown from irradiated seeds were more resistant to cold. Increased yields of field cucumbers under the conditions of Poland are also confirmed by a study conducted by Klimont (2002), and in the conditions of Bulgaria - a study conducted by Vasilevski and Bosev (1997). In the research by Klimont (2002), 4- and 6-time laser exposure did 
not affect the yield of two field tomato cultivars. Vasilevsky and Bosev (1997) noted an increase in the yields of onion (15.5\%), common bean (27\%), and peppers (13\%), including the early yield - by $19-24 \%$.

Klimont (2001) demonstrated that 2-6-time irradiation of French bean seeds caused an increase of seed yield of the two cultivars of the species by $8.2-$ $19.0 \%$. That was the result of an increase in the number of pods per plant and in the weight of 1000 seeds.

Studies by Klimont (2001) and by Podleśna et al. (2015) demonstrated that multiple irradiation of pea seeds caused an increase of yields by 5.6-21.6\% and $6.2-6.4 \%$, respectively. In both experiments, the increase of yield was caused by a greater number of pods and seeds per plant. The irradiation had no significant effect on the number of seeds in a pod. Podleśna et al. (2015) observed certain differences in growth and development between plants grown from irradiated and control seeds. Plants that grew from stimulated seeds were taller and they flowered and ripened 3-4 days earlier than plants developed from control seeds. The differences between the compared groups of plants were noted throughout the growth period, but they were significant in the phase of blooming. The earlier ripening of plants grown from stimulated seeds was also expressed in a lower content of water in seeds, compared to seeds from the control. Plants grown from irradiated seeds produced leaves with larger area than plants from control seeds.

Osman et al. (2009) demonstrated that irradiation of seeds of fennel and coriander using a $\mathrm{He}-\mathrm{Ne}$ laser contributed to a stronger branching of plants and to an increase in the number of umbels. There was also an increase in the content of essential oil in the fruits. The best effects were obtained as a result of 20-minute irradiation, compared to stimulation for a shorter time (5 and 10 minutes) and to the untreated control.

Stimulation of scorzonera seeds with $\mathrm{He}-\mathrm{Ne}$ laser light can cause an increase of root yield. A study by Krawiec et al. (2016) demonstrated that the yield increase was not, however, an effect of increased mass of the roots but rather of an increase in the rate of emergence as a result of pre-sowing irradiation of seeds. In a year when no improvement of emergence was noted, no increase in root yield was observed. Pre-sowing treatment of seeds with laser light had no effect on root mass.

A positive effect of the laser light exposure on the content of sugars in sugar beet roots was observed in the studies conducted by, e.g. - Inyushin et al. (1981), Koper (1994) and by Sacała et al. (2012). Dobrowolski et al. (1992) demonstrated an effect of laser light on the content of certain microelements in tomato fruits. Osman et al. (2009), mentioned above, noted an increase of the main components of essential oil contained in fruits of fennel and coriander as a result of irradiation of seeds.

A majority of the available publications prove positive effects of laser light, but one can also find studies in which no positive effect of the dose of irradiation on the values of the studied traits of plants was noted. Roszko and Michalik (2002) demonstrated that the stimulation of carrot seeds with $\mathrm{He}$ Ne laser light did not have any positive effect on the germination capacity of the seeds, in spite of the fact that the scope of the study conducted by those authors was very broad. In their experiment, they analysed the effect of 2-, 4-, 6-, 8-, 10- and 12-time irradiation. The emergence rates of seedlings from irradiated and control seeds did not differ from each other. The stimulation of the seeds had also no effect on the dynamics of seed germination and seedling emergence. The total and commercial yields of carrot roots obtained from plots sown with control seeds did not differ from the yield of roots from plots sown with stimulated seeds. In the opinion of the authors, carrot is one of those species that are resistant to the positive effect of laser light.

Szajsner and Drozd (2007) demonstrated that in the case of such species as cucumber, peppers and tomato, the variety was the primary factor differentiating the effect of pre-sowing irradiation with a semiconductor laser on seed germination energy and capacity and on the length of the radicle and the aboveground part of the seedling. Some cultivars responded positively to laser stimulation of seeds, others did not. Similar results were obtained by Klimont $(2001,2002)$ in relation to the cultivars of pea, beans, cucumber and tomato after the application of irradiation with the use of He-Ne laser.

All the authors who studied the impact of laser stimulation emphasize that the level of effects 
obtained depends on a number of factors, such as the species, variety, method of irradiation, dose of radiation, and also largely on the thermal-moisture conditions under which the plants grow and develop (Podleśny 2000; Hernandez et al. 2010; Soliman \& Harith 2010; Aladjadjiyan 2011; Krawiec et al. 2015). It can be supposed that for certain plant species, there is a certain range of radiation within which all doses have a similar stimulating effect on seeds. Only after that range of radiation is exceeded, there often occurs a negative effect of irradiation that may lead to deterioration of traits such as germination inhibition and a reduction of emergence rate (Podleśny 2000; Muszyński \& Gładyszewska 2008).

\section{Magnetic field}

The Earth has a variable magnetic field. Depending on the latitude, its intensity varies from 0 to $67 \mu \mathrm{T}$. It is a natural element of the environment of all organisms living on Earth (Belyavskaya 2004). Plants are well adapted to life in the natural magnetic field. Their isolation from its effect causes unfavorable symptoms, such as growth inhibition and disturbance of their tropism.

Studies by various authors indicate that the treatment of seeds with magnetic field of suitable parameters had a positive effect on the process of germination, seedling emergence, growth and yields of crop plants. The biostimulative impact usually depends on the following factors: magnetic induction, frequency of alternating fields, seed exposure time, and polarity (north or south) (Phirke et al. 1996; Hernandez Aguilar et al. 2009; Martínez et al. 2009; Teixeira da Silva \& Dobránszki 2016). Both static (i.e., stationary) and alternating magnetic fields have been used for seed stimulation. The induction of fields used for seed treatment varied from $3 \mathrm{mT}$ (Soltani et al. 2006a) to $480 \mathrm{mT}$ (Zepeda-Bautista et al. 2010). The exposure time was from $4 \mathrm{~s}$ to $24 \mathrm{~h}$ (Prokop et al. 2002, Zepeda-Bautista et al. 2010). As indicated by some studies, the effectiveness of magnetic field effect on seeds depends also on the species and the cultivar (Podleśny et al. 2004; Teixeira da Silva \& Dobránszki 2016).

Treatment of seeds with magnetic field had a positive effect on the germination energy (Kubisz et al. 2012; Krawiec et al. 2013; Hołubowicz et al.
2014). Stimulation of onion seeds with low frequency magnetic field (LFMF) $20 \mathrm{mT}$ for 10, 20 and 30 minutes caused an increase of that parameter. The longer the time of exposure, the higher was the energy of seed germination. Depending on the cultivar, the increase of germination energy was from 5.0 to $22.5 \%$ (Hołubowicz et al. 2014). An improvement of that parameter was also observed by Krawiec et al. (2013) in a study on the stimulation of radish seeds with alternating magnetic field of induction of 30 and $60 \mathrm{mT}$. The increase of germination energy was $0.5-19.2 \%$ depending on magnetic induction and seed lot. The most advantageous effects of magnetic stimulation were observed for old seeds, i.e., 7-8 years old (with initial germination capacity of $66.5-75.5 \%$ ). Their germination energy increased by $12.3-19.2 \%$, depending on the seed lot and value of magnetic induction applied.

Magnetic field stimulation also caused an improvement of seed germination capacity. Hołubowicz et al. (2014) noted an increase of germination capacity of onion seeds stimulated with magnetic field, by $2.5-13.7 \%$ relative to the control. Extension of the time of treatment with LFMF from 10 to 60 minutes caused an increase of germination capacity by $5.0-5.2 \%$, depending on the cultivar. An improvement of that parameter was also obtained by Krawiec et al. (2013), treating old radish seeds (7-8 years old) with magnetic field with induction of 30 and $60 \mathrm{mT}$. High quality seeds of the species (with initial germination capacity of 88.3-92.5\%) did not respond with any improvement of the parameter. Alexander and Doijode (1995) also reported a positive effect of magnetic field with $10.8 \mathrm{mT}$ on low viability onion seeds. In their experiment, the initial viability of onion seeds was only $41 \%$. After the magnetic field treatment, the germination capacity increased up to $56 \%$.

Treatment of tomato seeds with static magnetic field with induction of 125 and $250 \mathrm{mT}$ and exposure times of $1 \mathrm{~min}$ to $24 \mathrm{~h}$ shortened the time required for the germination of 1-90\% of the seeds. The germination rate of the treated seeds was higher than that of the untreated seeds. The mean germination time was significantly reduced compared to control (Martínez et al. 2009). Static magnetic field with $3 \mathrm{mT}$ increased the germination rate of Ocimum 
basilicum seeds (Soltani et al. 2006a). Asparagus seeds treated with static magnetic field imbibed and germinated more rapidly. Seed germination percentage was also higher than without the influence of a magnetic field (Soltani et al. 2006b). Treatment of marigold seeds with magnetic field with induction of 50, 75, 100 and $125 \mathrm{mT}$ affected the improvement of the following germination parameters: mean germination time, time needed to $50 \%$ germination, final germination percentage (Afzal et al. 2012). Chao and Walker (1967) studied germination of apple, apricot and peach seeds after magnetic field treatment of $60 \mathrm{mT}$. All the apple seeds germinated within 18 days in a magnetic field and 25 days without it. In apricot, the treated seeds completed germination in 10 days as against 20 days in the case of untreated seeds. In both species, the germination percentage was greater in the treated seeds than the untreated seeds. None of the peach seeds germinated under the magnetic stimulation although some untreated seeds did.

Seed stimulation with magnetic field caused an improvement and an acceleration of emergence of crop plants. LFMF with $20 \mathrm{mT}$ for $60 \mathrm{~min}$ increased the field emergence of onion compared to the control seeds and seeds treated for 10 and 20 min (Hołubowicz et al. 2014). Magnetic field treatment of marigold seeds with 25, 50, 75, 100 and $125 \mathrm{mT}$ for 3 min improved emergence and reduced mean emergence time and time to reach $50 \%$ emergence compared to the control (Afzal et al. 2012). Magnetic field irradiation of pea seeds with 30 and $85 \mathrm{mT}$ for $15 \mathrm{~s}$ improved the emergence of seedlings. Under the conditions of water deficit in soil better effects of the treatment on emergence were obtained than under the conditions of optimum soil moisture (Podleśny \& Pietruszewski 2007). The emergence of broad bean plants from seeds treated with an alternating magnetic field of 30 and $85 \mathrm{mT}$ was noted some 2 days earlier in comparison with the control (Podleśny et al. 2004). Whereas, the emergence of pea from seeds treated with the same factors was earlier by 2-3 days (Podleśny et al. 2005).

Additionally, some researchers indicated that the improvement of seed germination and seedlings emergence was accompanied by the elongation of radicles and primary stem as well as increase of seedling fresh or dry weight (Soltani et al. 2006a; Hernandez Aguilar et al. 2009).

Seedlings of onion grown from seeds treated with magnetic field with induction of $20 \mathrm{mT}$ and exposure times of 10, 20 and 30 min were longer than those grown from control seeds. The longest were those seedlings that were developed from seeds stimulated for the longest time (Hołubowicz et al. 2014). Stimulation of radish seeds with magnetic field with induction of 30 and $60 \mathrm{mT}$ caused an elongation of the hypocotyl and of the radicle of seedlings (Krawiec et al. 2013). Treatment of old seeds of onion with magnetic field with induction of $10.8 \mathrm{mT}$ caused an elongation of the shoot by $18.5-$ $51.9 \%$ and of the radicle by $33.3-88.9 \%$. As a result of seed stimulation, an increase was noted also in the seedling fresh weight and seedling dry weight (Alexander \& Doijode 1995).

Treatment with a static magnetic field of $250 \mathrm{mT}$ produces an increase in the first stages of growth of tomato plants (Martínez et al. 2009). Magnetic field treatments with 60,120,180 mT for 5,10 and $15 \mathrm{~min}$ had a positive effect on root and shoot length and dry and fresh mass of pea seedling (Iqbal et al. 2012). Magnetic field treatment with 25, $50,75,125 \mathrm{mT}$ for $3 \mathrm{~min}$ enhanced significantly the root and shoot length of marigold seedling (Afzal et al. 2012). Static magnetic field increased the length of radicles and stems of basil and asparagus seedlings (Soltani et al. 2006a, b).

Seed stimulation with magnetic field caused an improvement of yields of crop plants. The treatment of broad bean seeds with a magnetic field prior to sowing had a significant influence on seed yield. Plants grown from treated seeds produced more seeds than those obtained from untreated seeds. No influence was observed concerning this treatment on the number of seeds per pod or the weight of 1000 seeds (Podleśny et al. 2004). A few days' acceleration in the maturity of the broad bean was recorded. Plant ripen more rapidly when the seeds have been treated with a magnetic field. Boe and Solunkhe (1963) proved that tomatoes ripen earlier as a result of the influence of a magnetic field. The pre-sowing treatment of pea seeds with magnetic field produced a significant increase in seed yield. An increase in seed yield due to the pre-sowing 
stimulation resulted from a bigger pod complement and lower plant losses from a surface unit during vegetation (Podleśny et al. 2005).

The LFMF used on seeds of onion 'Octavia' had no effect on the fresh weight of the 3-month-old plants grown from these seeds when exposed for 10 and $30 \mathrm{~min}$, but when treated for $60 \mathrm{~min}$, the plant fresh weight, root length, and maximal diameter of the bulb increased (Hołubowicz et al. 2014). The yield of radish grown from seeds treated with a magnetic field with induction of $30,60,100 \mathrm{mT}$ and exposure times of 4 and $60 \mathrm{~s}$ increased by 20 $105 \%$ compared to the untreated control (Prokop et al. 2002).

The field experiment carried out by De Souza et al. (2006) indicated that pre-sowing magnetic field stimulation with $100 \mathrm{mT}$ for $10 \mathrm{~min}$ and $170 \mathrm{mT}$ for $3 \mathrm{~min}$ enhanced the growth and yield of tomato. In the vegetative stage, the treatment led to a significant increase in leaf area and leaf dry weight. The leaf, stem and root relative growth rates of plants derived from magnetically treated seeds were greater than those shown by the control plants. At fruit maturity stage, magnetic treatment increased significantly the mean fruit weight, the fruit yield per plant, the fruit yield per area. Additionally, a significant delay in the appearance of first symptoms of geminivirus and early blight and reduced infection rate of early blight were observed in the plants from seeds exposed to magnetic fields.

The mechanism of the stimulating effect of magnetic field on seed germination is not well known yet, but several theories have been proposed. Some of them attribute the effect to biochemical changes or altered enzyme activities. The results obtained by Aksenov et al. (1996) indicate that the impact of low frequency magnetic field at the stage of release of the enzyme called esterase in the course of swelling of wheat seeds greatly speeds up the release of enzymes from the bound state and also the release of seeds from the dormant stage. Later, the field effects decrease appreciably. García Reina et al. (2001) suggested the hypothesis that magnetic field interacts with ionic currents in the embryo cell membrane. The magnetic field causes changes in the ionic concentration and in the osmotic pressure, which regulates the entrance of water to the seeds.
Magnetically treated seeds absorb more water and absorb it faster than untreated seeds. This result could be an explanation of the effect of magnetic field on germination rate and germination speed of seeds and, in consequence, on the enhancement of plant growth and crop yield.

\section{Magnetized water}

Another way of applying a magnetic field is the use of magnetically treated water (magnetized water). Irrigation with magnetized water can improve the growth and development of plants. It can improve the germination of seeds, early vegetative development of seedlings, and can also alter the mineral content of seeds and fruits (Teixeira da Silva \& Dobránszki 2014).

Magnetized water (MW) is usually obtained by passing water between the pole shoes of a permanent magnet or an electromagnet. The effects of magnetized water treatment depend on the magnetic induction and exposure period of water conditioning, quality and volume of water, the speed of flow and water temperature (Goldsworthy et al. 1999; Pang \& Deng 2008). An externally applied magnetic field causes changes in atomic, molecular and electronic structure of the treated water. Magnetized water causes an increase of permeability of cell membranes to calcium ions and inhibition of the growth of pathogenic microorganisms. Treatment with magnetized water also causes an increase of electric conductivity and a decrease of surface tension (Goldsworthy et al. 1999; Coey \& Cass 2000; Biryukov et al. 2005). In the study conducted by Goldsworthy et al. (1999), weakly conditioned water with pulsed $100 \mathrm{kHz}$ electromagnetic field for 5$30 \mathrm{~s}$ stimulated the growth of yeast cultures. According to these authors, the conditioned water interact with the structural calcium in the cell membrane to make it more permeable. Weak treatment gives a slight increase in permeability and allows the ingress of small amounts of external calcium, which activates the calcium signaling cascade and promotes growth. Strongly conditioned water (treated for $2 \mathrm{~min}$ ) causes more severe membrane damage, which disrupts metabolism and inhibits growth.

In the study by Pietruszewski et al. (2007), the water magnetized as a result of 1,3 and 10-time 
passage through a magnetic field with induction of $75 \mathrm{mT}, 300 \mathrm{mT}$ and $900 \mathrm{mT}$ was used for the stimulation of tomato and cucumber seeds. Tomato seeds treated with all MW combinations revealed an increase of germination rate by ca. $5 \%$. In the case of cucumber seeds, an increase of germination capacity by $13 \%$ and $15 \%$, respectively, was noted for 1- and 10-time passage and induction of $300 \mathrm{mT}$.

Ul Haq et al. (2016) used magnetically treated water at $211 \mathrm{mT}$ for 30, 45 and $60 \mathrm{~min}$ for turnip seed irrigation. Magnetic water caused an increase of the germination percentage and emergence rate by up to $28.3 \%$ and $11.5 \%$, respectively. The growth parameters, such as seedling length, fresh and dry weights, chlorophyll content, were also enhanced. Seedlings irrigated with magnetically treated water showed higher protein content, alpha amylase and protease activities.

Podsiadło and Leśniak (2008) applied magnetized water obtained as a result of one-time passage through a magnetizer with working pressure of $0.6 \mathrm{MPa}$, at average water flow rate of $2.25 \mathrm{~m}^{3} \cdot \mathrm{h}^{-1}$, induction of $0.30 \mathrm{~T}$, for the stimulation of seeds of various plant species. MW caused an increase of germination capacity of yellow lupine by $4 \%$, white mustard by $11 \%$, corn salad by $10 \%$, sowing coriander by $5 \%$, compared to control seeds. In another experiment by Podsiadło and Leśniak (2009), magnetized water had a positive effect on the germination and growth rate of seedlings of sowing coriander and field cucumber. A study by Podsiadło (2013) demonstrated a positive effect of MW on the germination and initial growth of seedlings of herbs - summer savory, sowing coriander, marjoram and common chamomile.

Magnetized water was applied successfully for the stimulation of the process of germination of seeds of Pinus tropicalis M. The results showed an increase in the germination percentage up to 70 $81 \%$ with respect to the control samples $(43 \%)$, as well as greater seedling growth after germination (Morejón et al. 2007).

A study conducted in Egypt indicates that magnetic stimulation of seeds and of water applied for their irrigation can be used for the limitation of side effects of water deficit during plant growth. Tomato plants grown from seeds treated with magnetic field and watered with magnetized water fared better under conditions of water deficit (40 and 60\% of capacity) than plants grown from non-treated seeds. The better condition of the plants was evidenced by such parameters as height, root length, leaf area and number, fresh and dry mass, content of photosynthetic pigments (Selim \& El-Nady 2011).

Some research showed that magnetic treatment of irrigation water can be more effective than magnetic treatment of seeds for seedling emergence and seedling growth. An investigation conducted by Grewal and Maheshwari (2011) indicated that magnetic treatment of irrigation water caused an increase in seedling emergence of snow pea, shoot dry weight and contents of $\mathrm{N}, \mathrm{K}, \mathrm{Ca}, \mathrm{Mg}, \mathrm{S}, \mathrm{Na}, \mathrm{Zn}, \mathrm{Fe}$ and Mn compared not only to control but also to magnetic treatment of seeds.

The results of the cited studies suggest that magnetically treated water have the potential to improve the early seedling growth and nutrient contents of seedlings.

\section{Electric field}

Studies on the effect of electric field on seeds involved the use of constant electric fields, alternating electric fields, pulse electric fields, and various forms of discharge, such as corona discharge or cold plasma. Seed treatment with those factors had a positive effect on germination, seedling growth, and on the yielding of plants grown from the seeds (Moon \& Chung 2000; Prokop et al. 2002; Krawiec et al. 2012).

Studies of Nelson et al. (1970) demonstrated that brief exposures to radiofrequency electric fields at frequencies of about $40 \mathrm{MHz}$ and field intensities in the range from 1 to $2 \mathrm{kV} \cdot \mathrm{cm}^{-1}$ substantially increased the germination of okra, peas and beans by reducing the percentage of hard seeds. The electric treatment accelerated spinach seed germination and emergence.

Moon and Chung (2000) treated tomato seeds with an alternating electric field in the range of 4 to $12 \mathrm{kV} \cdot \mathrm{cm}^{-1}$, exposure time of 15 to $60 \mathrm{~s}$, frequency of $60 \mathrm{~Hz}$. Seed stimulation with electric field in that range accelerated germination by $1.1-2.8$-fold in 5 days incubation. Those authors found a negative effect of field with intensity above $12 \mathrm{kV} \cdot \mathrm{cm}^{-1}$ and exposure time longer than $60 \mathrm{~s}$, which inhibited the germination of seeds of the species. 
The application of an alternating electric field with frequency of $50 \mathrm{~Hz}$, intensity of $8 \mathrm{kV} \cdot \mathrm{cm}^{-1}$ and for time $30 \mathrm{~s}$ had an effect on the germination of seeds of radish 'Mila', causing an improvement of the germination parameters of old seeds (7-year old). An increase of germination energy and capacity was observed, a shortening of time required for the germination of $25 \%$ and $50 \%$ of the total number of germinating seeds, as well as of the mean time of germination of a single seed. The stimulation had also a positive effect on the increase of dry mass of seedlings (Krawiec et al. 2012). In the study conducted by Pietruszewski and Kornarzyński (2002), the seeds of tomato 'Halicz' with a low germination capacity (46\%) were stimulated with fields of intensities $5 \mathrm{kV} \cdot \mathrm{cm}^{-1}$ and $10 \mathrm{kV} \cdot \mathrm{cm}^{-1}$, frequency of $50 \mathrm{~Hz}$, for time $100 \mathrm{~s}$. The germination capacity of treated seeds increased to approx. $80 \%$.

Prokop et al. (2002) studied the effect of stimulation of seeds of radish 'Carmen' and skall radish 'Agata' and 'Murzynka' with an alternating electric field with intensity of 5 and $10 \mathrm{kV} \cdot \mathrm{cm}^{-1}$, frequency of $50 \mathrm{~Hz}$, for $4 \mathrm{~s}$ and $60 \mathrm{~s}$, on the root yield. The treatment of the seeds caused an increase of radish yield by $105 \%$ and an increase of root yield in the range from 20 to $105 \%$. The low exposure dose of the electric field caused an increase of yield of skall radish 'Murzynka', while the high dose $\left(10 \mathrm{kV} \cdot \mathrm{cm}^{-1}\right.$ and $60 \mathrm{~s}$ ) caused a decrease of the yield.

Seven-day old seedlings of thale cress (Arabidopsis thaliana) were subjected to the effect of nanosecond pulsed electric fields (nsPEF) with duration of $10 \mathrm{~ns}, 25 \mathrm{~ns}$ and $100 \mathrm{~ns}$ for field intensities from 5 to $50 \mathrm{kV} \cdot \mathrm{cm}^{-1}$. It was found that the leaf area increased two-fold after 5 and 7 days from the stimulation for the time of $10 \mathrm{~ns}$ and low amplitudes of intensity of the field of $5 \mathrm{kV} \cdot \mathrm{cm}^{-1}$. However, the application of longer pulses (100 ns) and high intensities of electric field caused the death of the seedlings. The authors suggest that this might have been caused by the release of calcium from internal stores, which was observed in the action of nsPEF on the cells of mammals (Eing et al. 2009).

$\mathrm{Su}$ et al. (2015) studied the effect of pulsed electric field (nsPEFs) with intensity of 10, 20 and $30 \mathrm{kV} \cdot \mathrm{cm}^{-1}$ and $100 \mathrm{~ns}$ on seed germination and on the height of seedlings of the tree saxaul (Haloxylon ammodendron). An increase of seed germination rate from $72.9 \%$ to $90.3 \%$ and $98 \%$, respectively, was noted for the field intensities of 10 and $20 \mathrm{kV} \cdot \mathrm{cm}^{-1}$. The effect of seed stimulation with a field with intensity of $30 \mathrm{kV} \cdot \mathrm{cm}^{-1}$ was a decrease of germination capacity to $55.7 \%$. This may indicate that strong electric fields can have an unfavorable effect on seed germination.

Grzesik et al. (2017) used pulsed electric field (Pulsed Radio Frequency - PRF) to alleviate apple seed dormancy. Seeds were exposed to PRF for $1 \mathrm{~h}$, at a constant voltage of $25 \mathrm{~V}$, pulse repetition rates $4 \mathrm{~Hz}$ with pulse duration $20 \mathrm{~ms}$. PRF applied alone during stratification or together with selected phytohormones and compounds increased percentage and dynamics of seed germination of apple 'Ligol' as well as dynamics of seedlings growth.

Corona discharge finds an application in agriculture for seed sorting. Corona discharge takes place when electric current passes through the air from a discharge electrode connected to a high voltage. Carrot seeds were subjected to the treatment by means of a cylindrical electrical separator type PTV-1 with electric field intensity $\mathrm{E}=3 \times 10^{5} \mathrm{~V} \cdot \mathrm{m}^{-1}$ during corona discharges. The separator separated dead seeds from viable ones, and at the same time stimulated them for $2 \mathrm{~s}$ in the course of their separation. Research showed that carrot seed stimulation with corona discharge field increased germination by $7-19 \%$ (Lynikiene 2001). Lynikiene et al. (2006) stimulated seeds of carrot, radish and red beet with the use of electric field of corona discharge with parameters as mentioned above. Under the effect of the field, the germination capacity of carrot seeds increased by $24 \%$, that of seeds of radish and red beet by $12 \%$. In the case of seeds with a low germination capacity, the stimulation accelerated their germination by as much as $2-3$ days.

\section{CONCLUSION}

This literature review demonstrates that seed treatment with mentioned physical factors can be a very effective way of seed quality improvement of horticultural and herbal plants. The beneficial effects of seed stimulation are mainly related to the first stages of plant life, i.e. - germination, emergence 
and growth of seedlings. In many cases, the enhancement of these features is also the result of the increase of plant yields. The increase of yield is even several dozen percent. The results of the study encourage the implementation of these physical methods of seed quality improvement into agricultural and horticultural practice. The first step towards their popularization will be the construction of devices for mass stimulation of seeds. This will increase the cost-effectiveness of these methods of seed quality improvement in practice, as the test equipment was adapted to small-scale seed processing.

\section{Author contributions}

M.K. - laser light, M.K. and A.D-H. - magnetic field, K.K. and M.K. - magnetized water and electric field

Conflict of interest

Authors declare no conflict of interest.

\section{REFERENCES}

Afzal I., Mukhtar K., Qasim M., Basra S.M.A., Shahid M., Haq Z. 2012. Magnetic stimulation of marigold seed. International Agrophysics 26: 335-339. DOI: 10.2478/v10247-012-0047-1.

Aksenov S.I., Bulychev A.A., Grunina T.Yu., Turovetskii V.B. 1996. Mechanisms of the action of a low-frequency magnetic field on the initial stages of germination of wheat seeds. Biophysics 41(4): 931-937.

Aladjadjiyan A. 2011. Physical factors for plant growth stimulation improve food quality. In: Aladjadjiyan A. (Ed.), Food Production - Approaches, Challenges and Tasks. Intech, Croatia, pp. 145-168. DOI: $10.5772 / 32039$.

www.cdn.intechopen.com/pdfs/26521.pdf [04.05.2018]

Alexander M.P., Doijode S.D. 1995. Electromagnetic field, a novel tool to increase germination and seedling vigour of conserved onion (Allium cepa L.) and rice (Oryza sativa L.) seeds with low viability. Plant Genetic Resources Newsletter 105: 1-5.

Belyavskaya N.A. 2004. Biological effects due to weak magnetic field on plants. Advances in Space Research 34: 1566-1574. DOI: 10.1016/j.asr.2004.01.021.

Bewley J.D., Black M. 1985. Seeds: Physiology of Development and Germination. Plenum Press, USA.

Biryukov A.S., Gavrikov V.F, Nikiforova L.O., Shcheglov V.A. 2005. New physical methods of disinfection of water. Journal of Russian Laser Research 26(1): 13-25. DOI: 10.1007/s10946-005-0002-8.
Boe A.A., Salunkhe D.K. 1963. Effects of magnetic fields on tomato ripening. Nature 199: 91-92. DOI: 10.1038/199091a0.

Brutnell T. 2006. Phytochrome and light control of plant development. In: Taiz L., Zeiger E. (Eds.), Plant Physiology. Sinauer Associates, USA, pp. 417-443.

Chao L., Walker D.R. 1967. Effect of magnetic field on germination of apple, apricot and peach seed. HortScience 2: 152-153.

Chen Y.-P., Liu Y.-J., Wang X.-L., Ren Z.-Y., Yue M. 2005 a. Effect of microwave and He-Ne laser on enzyme activity and biophoton emission of Isatis indigotica Fort. Journal of Integrative Plant Biology 47(7): 849-855. DOI: 10.1111/j.17447909.2005.00107.x.

Chen Y.-P., Yue M., Wang X.-L. 2005 b. Influence of He-Ne laser irradiation on seeds thermodynamic parameters and seedlings growth of Isatis indigotica. Plant Science 168: 601-606. DOI: 10.1016/j.plantsci.2004.09.005.

Coey J.M.D., Cass S. 2000. Magnetic water treatment. Journal of Magnetism and Magnetic Materials 209: 71-74. DOI: 10.1016/s0304-8853(99)00648-4.

Dakowska S., Jędryczka M., Rybiński W. 2001. Wpływ światła lasera helowo-neonowego na przeżywalność grzybów w nasionach rzepaku. AGROLASER, 2628 September, Lublin, pp. 128-130. [in Polish]

De Souza A., García D., Sueiro L., Gilart F., Porras E., Licea L. 2006. Pre-sowing magnetic treatments of tomato seeds increase the growth and yield of plants. Bioelectromagnetics 27: 247-257. DOI: 10.1002/bem.20206.

Dobrowolski J.W., Smyk B., Różycki E., Barabasz W., Wąchalewski T. 1992. Experiments about the influence of laser light on some biological elements of the natural environment. Acta Universitatis Upsaliensis 1: 1-15.

Drozd D., Szajsner H. 2007. The reaction of seeds of some cucumber cultivars to pre-sowing laser biostimulation. Roczniki Akademii Rolniczej w Poznaniu 383, Ogrodnictwo 41: 455-459. [in Polish with English abstract]

Eing Ch.J., Bonnet S., Pacher M., Puchta H., Frey W. 2009. Effects of nanosecond pulsed electric field exposure on Arabidopsis thaliana. IEEE Transactions on Dielectrics and Electrical Insulation 16(5): 1322-1328. DOI: 10.1109/tdei.2009.5293945.

Ellis R.H. 1992. Seed and seedling vigour in relation to crop growth and yield. Plant Growth Regulation 11: 249-255. DOI: 10.1007/bf00024563. 
Finch-Savage W.E., Bassel G.W. 2016. Seed vigour and crop establishment: extending performance beyond adaptation. Journal of Experimental Botany 67(3): 567-591. DOI: 10.1093/jxb/erv490.

García Reina F., Arza Pascual L., Almanza Fundora I. 2001. Influence of a stationary magnetic field on water relations in lettuce seeds. Part II: Experimental results. Bioelectromagnetics 22: 596-602. DOI: $10.1002 /$ bem.89.

Gładyszewska B. 2011. Estimation of a laser biostimulation dose. International Agrophysics 25: 403-405.

Gładyszewska B., Koper R., Kornarzyński K. 1998. Technology and effects of the pre-sowing laser biostimulation of cucumber seeds. Zeszyty Problemowe Postępów Nauk Rolniczych 454: 213-219. [in Polish with English abstract]

Goldsworthy A., Whitney H., Morris E. 1999. Biological effects of physically conditioned water. Water Research 33(7): 1618-1626. DOI: 10.1016/s00431354(98)00395-9.

Grewal H.S., Maheshwari B. L. 2011. Magnetic treatment of irrigation water and snow pea and chickpea seeds enhances early growth and nutrient contents of seedlings. Bioelectromagnetics 32(1): 58-65. DOI: $10.1002 /$ bem.20615.

Grzesik M., Górnik K., Janas R., Lewandowski M., Romanowska-Duda Z, van Duijn B. 2017. High efficiency stratification of apple cultivar Ligol seed dormancy by phytohormones, heat shock and pulsed radio frequency. Journal of Plant Physiology 219: 81-90. DOI: 10.1016/j.jplph.2017.09.007.

ul Haq Z., Iqbal M., Jamil Y., Anwar H., Younis A., Arif M. et al. 2016. Magnetically treated water irrigation effect on turnip seed germination, seedling growth and enzymatic activities. Information Processing in Agriculture 3: 99-106. DOI: 10.1016/j.inpa.2016.03.004.

Hernandez A.C., Carballo C.A., Artola A. Michtchenko A. 2006. Laser irradiation effects on maize seed field performance. Seed Science and Technology 34(1): 193-197. DOI: 10.15258/sst.2006.34.1.21.

Hernandez Aguilar C., Dominguez-Pacheco A., Carballo Carballo A., Cruz-Orea A., Ivanov R., López Bonilla J.L., Valcarcel Montañez J.P. 2009. Alternating magnetic field irradiation effects on three genotype maize seed field performance. Acta Agrophysica $14(1)$ : 7-17.

Hernandez A.C., Dominguez P.A., Cruz O.A., Ivanov R., Carballo C.A., Zepeda B.R. 2010. Laser in agriculture. International Agrophysics 24: 407-422.
Hoffmann F. 1996. Laser microbeams for the manipulation of plant cells and subcellular structures. Plant Science 113: 1-11. DOI: 10.1016/01689452(95)04279-2.

Hołubowicz R., Kubisz L., Gauza M., Tong Y., HojanJezierska D. 2014. Effect of low frequency magnetic field (LFMF) on the germination of seeds and selected useful characters of onion (Allium cepa L.). Notulae Botanicae Horti Agrobotanici Cluj-Napoca 42(1): 168-172. DOI: 10.15835/nbha4219131.

Инюшин В., Ильясов Г.У., Федорова Н.Н. 1981. Лазерный свет и урожай. Кайнар, Алма-Ата [in Russian]

Iqbal M., Haq Z.U., Jamil Y., Ahmad M.R. 2012. Effect of presowing magnetic treatment on properties of pea. International Agrophysics 26: 25-31. DOI: 10.2478/v10247-012-0004-z.

Klimont K. 2001. The influence of the laser biostimulation on the yield and seed quality of bean (Phaseolus vulgaris L.) and pea (Pisum sativum L.). Biuletyn IHAR 217: 263-277. [in Polish with English abstract]

Klimont K. 2002. Studies of laser biostimulation on sowing value of seeds and yield of tomato (Lycopersicon esculentum Mill.) and cucumber (Cucumis sativus L.). plants. Biuletyn IHAR 223-224: 257266. [in Polish with English abstract]

Koper R. 1993. Urządzenie do obróbki przedsiewnej nasion promieniowaniem laserowym. Patent $\mathrm{RP} \mathrm{Nr}$ 162598. [in Polish]

Koper R. 1994. Pre-sowing laser biostimulation of seeds of cultivated plants and its results in agrotechnics. International Agrophysics 8: 593-596.

Krawiec M., Dziwulska-Hunek A. 2009. Effect of presowing laser stimulation on germination of pea seeds (Pisum sativum L.) and field emergence. Zeszyty Problemowe Postępów Nauk Rolniczych 539: 359-364. [in Polish with English abstract]

Krawiec M., Dziwulska-Hunek A., Kornarzyński K., Palonka S. 2012. Effect of selected physical factors on radish (Raphanus sativus L.) seeds germination. Acta Agrophysica 19(4): 737-748. [in Polish with English abstract]

Krawiec M., Kornarzyński K., Palonka S., Kapłan M., Baryła P., Kiczorowski P. 2013. Does the magnetic field improve the quality of radish seeds? Acta Scientiarum Polonorum, Hortorum Cultus 12(6): 93-102.

Krawiec M., Dziwulska-Hunek A., Sujak A., Palonka S. 2015. Laser irradiation effects on scorzonera (Scorzonera hispanica L.) seed germination and 
seedling emergence. Acta Scientiarum Polonorum, Hortorum Cultus 14(2): 145-158.

Krawiec M., Dziwulska-Hunek A., Palonka S., Kapłan M., Baryła P. 2016. Effect of laser irradiation on seed germination and root yield of scorzonera (Scorzonera hispanica L.). Acta Agrophysica 23(4): 621-631.

Kubisz L., Hołubowicz R., Gauza M., Li H., Hojan-Jezierska D., Jaroszyk F. 2012. Effect of low frequency magnetic field on germination of onion $(\mathrm{Al}$ lium cepa L.) seeds. Acta Physica Polonica A 121(1): 49-53. DOI: 10.12693/aphyspola.121.a-49.

Lynikiene S. 2001. Carrot seed preparation in a corona discharge field. CIGR Journal of Scientific Research and Development 3; 7 p.

Lynikiene S., Pozeliene A., Rutkauskas G. 2006. Influence of corona discharge field on seed viability and dynamics of germination. International Agrophysics 20(3): 195-200.

Martínez E., Carbonell M.V., Flórez M., Amaya J.M., Maqueda R. 2009. Germination of tomato seeds (Lycopersicon esculentum L.) under magnetic field. International Agrophysics 23: 45-49.

Moon J.-D., Chung H.-S., 2000. Acceleration of germination of tomato seed by applying AC electric and magnetic fields. Journal of Electrostatics 48(2): 103-114. DOI: 10.1016/s0304-3886(99)00054-6.

Morejón L.P., Castro Palacio J.C., Velázquez Abad L., Govea A.P. 2007. Simulation of Pinus tropicalis M. seeds by magnetically treated water. International Agrophysics 21: 173-177.

Murphy A. 2006. Auxin: the growth hormone. In: Taiz L., Zeiger E. (Eds.), Plant Physiology, $4^{\text {th }}$ ed. Sinauer Associates, USA, pp. 467-507.

Muszyński S., Gładyszewska B. 2008. Representation of $\mathrm{He}-\mathrm{Ne}$ laser irradiation effect on radish seeds with selected germination indices. International Agrophysics 22: 151-157.

Nelson S.O., Nutile G.E., Stetson L.E. 1970. Effect of radiofrequency electrical treatment on germination of vegetable seeds. Journal of the American Society of Horticultural Science 95(3): 359-366.

Osman Y.A.H., El Tobgy K.M.K., El Sherbini E.A. 2009. Effect of laser radiation treatments on growth, yield and chemical constituents of fennel and coriander plants. Journal of Applied Sciences Research 5(3): 244-252.

Pang X.F., Deng B. 2008. Investigation of changes in properties of water under the action of a magnetic field. Science in China Series, G - Physics, Mechanics and Astronomy 51: 1621-1632. DOI: 10.1007/s11433-008-0182-7.
Perveen R., Ali Q., Ashraf M., Al-Qurainy F., Jamil Y., Ahmad M.R. 2010. Effects of different doses of low power continuous wave He-Ne laser radiation on some seed thermodynamic and germination parameters, and potential enzymes involved in seed germination of sunflower (Helianthus annuus L.). Photochemistry and Photobiology 86(5): 10501055. DOI: 10.1111/j.1751-1097.2010.00782.x.

Phirke P.S., Kubde A.B., Umbarkar S.P. 1996. The influence of magnetic field on plant growth. Seed Science and Technology 24(2): 375-392.

Pietruszewski S., Kornarzyński K. 2002. Technics of assistance tomato seeds germination used electric field and model this process with the help of logistic curve. Acta Scientiarum Polonorum, Technica Agraria 1(1): 83-88. [in Polish with English abstract]

Pietruszewski S., Kornarzyński K., Łopucki M. 2007. Woda magnetyczna, jej niektóre właściwości fizyczne i zastosowanie. Przegląd Telekomunikacyjny 80(8-9): 675-682. [in Polish]

Podleśna A., Gładyszewska B., Podleśny J., Zgrajka W. 2015. Changes in the germination process and growth of pea in effect of laser seed irradiation. International Agrophysics 29: 485-492. DOI: 10.1515/intag-2015-0054.

Podleśny J. 2000. Biostymulacja nasion światłem laserowym i jej wpływ na wzrost, rozwój oraz plonowanie roślin. Postępy Nauk Rolniczych 47(6): 27-39. [in Polish]

Podleśny J., Pietruszewski S. 2007. The effect of magnetic stimulation of seeds on growth and cropping of seed pea grown at varying soil moisture content. Inżynieria Rolnicza 8(96): 207-212. [in Polish with English abstract]

Podleśny J., Pietruszewski S., Podleśna A. 2004. Efficiency of the magnetic treatment of broad bean seeds cultivated under experimental plot conditions. International Agrophysics 18: 65-71.

Podleśny J., Pietruszewski S., Podleśna A. 2005. Influence of magnetic stimulation of seeds on the formation of morphological features and yielding of the pea. International Agrophysics 19: 61-68.

Podleśny J., Podleśna A. 2004. Morphological changes and yield of selected species of leguminous plants under the influence of seed treatment with laser light. International Agrophysics 18: 253-260.

Podleśny J., Stochmal A., Podleśna A., Misiak L.E. 2012. Effect of laser light treatment on some biochemical and physiological processes in seeds and seedlings of white lupine and faba bean. Plant Growth Regulation 67: 227-233. 
Podsiadło C. 2013. Effect of magnetyzed water on energy, germination and matter of selected species seedlings of herbs. Infrastructure and Ecology of Rural Areas 2(1): 215-224. [in Polish with English abstract]

Podsiadło C., Leśniak E. 2008. The impact of magnetically treated water on seeds sowing value and growth of selected plant species. Inżynieria Rolnicza 5(103): 195-200. [in Polish with English abstract]

Podsiadło C., Leśniak E. 2009. Influence of conditioned water on germination and initial of growth selected crop species. Infrastructure and Ecology of Rural Areas 3: 213-221. [in Polish with English abstract]

Prokop M., Pietruszewski S., Kornarzyński K. 2002. The preliminary investigation of magnetic and electric fields influence on germination, crops, and mechanical features of radish and skall radish roots. Acta Agrophysica 62: 83-93. [in Polish with English abstract]

Roszko A., Michalik B. 2002. Effect of laser irradiation on the quality of carrot seeds. Zeszyty Problemowe Postępów Nauk Rolniczych 488: 425-430. [in Polish with English abstract]

Sacała E., Demczuk A., Grzyś E., Prośba-Białczyk U., Szajsner H. 2012. Impact of presowing laser irradiation of seeds on sugar beet properties. International Agrophysics 26: 295-300. DOI: 10.2478/v10247-012-0042-6.

Selim A.-F.H., El-Nady M.F. 2011. Physio-anatomical responses of drought stressed tomato plants to magnetic field. Acta Astronautica 387-396. DOI: 10.1016/j.actaastro.2011.05.025.

Soliman A., Harith M.A. 2010. Effects of laser stimulation on germination of Acacia farnesiana (L.) Willd. Acta Horticulturae 854: 41-49. DOI: 10.17660/actahortic.2010.854.4.

Soltani F., Kashi A., Arghavani M. 2006 a. Effect of magnetic field on Ocimum basilicum seed germination and seedling growth. Acta Horticulturae 723: 279281. DOI: 10.17660/actahortic.2006.723.37.
Soltani F., Kashi A., Arghavani M. 2006 b. Effect of magnetic field on Asparagus officinalis L. seed germination and seedling growth. Seed Science and Technology 34(2): 349-353. DOI: 10.15258/sst.2006.34.2.10.

Su B., Guo J., Nian W., Feng H., Wang K., Zhang J., Fang J. 2015. Early growth effects of nanosecond pulsed electric field (nsPEFs) exposure on Haloxylon ammodendron. Plasma Processes and Polymers 12(4): 372-379. DOI: 10.1002/ppap.201400131.

Szajsner H., Drozd D. 2007. The improvement of seeds of selected vegetable species through laser radiation. Roczniki Akademii Rolniczej w Poznaniu 383, Ogrodnictwo 41: 625-629. [in Polish with English abstract]

Teixeira da Silva J.A., Dobránszki J. 2014. Impact of magnetic water on plant growth. Environmental and Experimental Biology 12: 137-142.

Teixeira da Silva J.A., Dobránszki J. 2016. Magnetic fields: how is plant growth and development impacted? Protoplasma 253(2): 231-248. DOI: 10.1007/s00709-015-0820-7.

Vasilevski G. 2003. Perspectives of the application of biophysical methods in sustainable agriculture. Bulgarian Journal of Plant Physiology (Special Issue) 29(3-4): 179-186.

Vasilevski G., Bosev D. 1997. Results of the effect of the laser light on some vegetables. Acta Horticulturae 462: 473-476. DOI: 10.17660/actahortic.1997.462.68.

Wilczek M., Koper R., Ćwintal M., Korniłłowicz-Kowalska T. 2005. Germination capacity and health status of alfalfa seeds after laser treatment. International Agrophysics 19: 85-89.

Wilde W.H.A., Parr W.H., McPeak D.W. 1969. Seeds bask in laser light. Laser Focus 5(23): 41-42.

Zepeda-Bautista R., Hernández-Aguilar C., DomínguezPacheco A., Cruz-Orea A., Godina-Nava J.J., Martínez-Ortíz E. 2010. Electromagnetic field and seed vigour of corn hybrids. International Agrophysics 24: 329-332. 